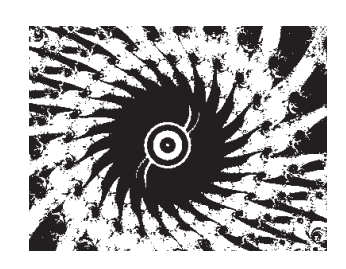

doi:10.5559/di.21.2.01

\title{
CORRUPTION SURVEY IN CROATIA: SURVEY CONFIDENTIALITY AND TRUST IN INSTITUTIONS
}

Jelena BUDAK, Edo RAJH

Institute of Economics, Zagreb

UDK: 328.185(497.5)"2010"

343.352(497.5):35.08

303.62(497.5)"2010":343.352

Izvorni znanstveni rad

Primljeno: 12. 4. 2011.

In an attempt to explore the linkages between corruption surveys, underreporting corruption experiences and causes of reluctance to report corruption, this paper provides insight into solutions applied to mitigate the underreporting risks in surveying corruption experiences in Croatia. Based on the Survey on use of public services and public integrity in Croatia 2010, the issue of underreporting corruption is assessed with a two-fold approach. The study first discusses the survey methodology applied, where the main concerns were the willingness of respondents to report corruption and their perceptions regarding risk of personal data misuse. Potential reluctance to admit involvement in corruption as a criminal act might be driven by a fear of subsequent surveillance or investigation. Further, we investigate the concerns expressed by respondents regarding the misuse of data and about protecting anonymity. Survey data were used to analyze citizens' attitudes and reasons for (not) reporting crime to official institutions. The analysis focuses on reporting corruption experiences, both formally and informally. The findings show a very high level of citizens' opportunism and lack of public trust in institutions that might impede anti-corruption efforts in Croatia.

Keywords: survey methodology, corruption experience, trust in institutions, reporting crime, Croatia

Jelena Budak, Institute of Economics, Trg J. F. Kennedyja 7, 10000 Zagreb, Croatia.

E-mail: jbudak@eizg.hr 
This paper provides insight into solutions applied to mitigate the underreporting risks in surveying corruption experiences in Croatia. Based on the Survey on use of public services and public integrity ${ }^{1}$ conducted in Croatia, we have analyzed a selection of questions and answers related to reporting corruption experiences. The survey was conducted in the summer of 2010 by face-to-face interviews with Croatian citizens, and provides data analysis of 3005 questionnaires. The methodology employed was carefully pre-tested in a pilot survey conducted in June 2010 on a net sample of 150 respondents. The pilot tested whether the option of self-administrated responses to questions related to corruption experiences would increase the response rate, and whether the respondents were concerned about the anonymity of the survey (Budak and Rajh, 2010). This research adds to the Budak and Rajh (2010) preliminary study of the pilot survey, which provided rather limited insight into the trust in institutions. Employing the data collected in the large nationally representative survey, this analysis extends to the public's confidence in institutions when reporting crime in Croatia.

Adding to the existing literature (Treisman, 2007; Jensen et al., 2007), when discussing the survey methodology, our main concerns were the willingness of respondents to report corruption and their perceived risk of personal data misuse. Potential reluctance to admit involvement in corruption as a criminal act might be driven by a fear of surveillance or investigation that might follow. Further, we have investigated the views expressed by respondents regarding the misuse of data, in particular with regard to protecting confidentiality. Due to the topic of the survey, the anonymity of the respondents was protected more than requested by standard market research procedures.

The issue of underreporting corruption is assessed here with a two-fold approach. The first one considers respondents' underreporting corruption experiences in the survey from the point of view of survey methodology applied. The other one arises from the direct survey results and refers to the issue of not reporting corruption experiences to official institutions. Thus the results of the survey enabled us to gain interesting insight into the public's trust in institutions in Croatia.

The paper is organized as follows. The next section describes the rationale for exploring the linkages between extensive corruption surveys, underreporting corruption experiences, and potential causes of reluctance to report corruption both in surveys and to the institutions. This background leads us to the main research questions: (i) whether respondents were 
DRUŠ. ISTRAŽ. ZAGREB GOD. 21 (2012), BR. $2(116)$

STR. $291-313$

BUDAK, J., RAJH, E.: CORRUPTION SURVEY.. reluctant to answer sensitive questions and why, and (ii) would Croatian citizens report crime, for what reasons, and which institutions they trust. The third section deals with the methodology and data used in the corruption survey conducted in Croatia, while the detailed empirical analysis results are elaborated in section four. The last section concludes with policy recommendations and suggests possible directions of further research.

\section{RATIONALE BACKGROUND}

Corruption is a world-wide phenomenon that has raised considerable research interest within the fields of sociological, political and economic studies. It has been investigated both theoretically and empirically from various aspects (Jain, 2001; Tanzi, 1998); however, the true prevalence of corruption still remains unrevealed (Kaufmann, 1997). The clandestine nature of this illegal activity together with different notions about what actions should be considered corruption are challenging researchers and policy makers to improve the methodology of corruption-related research (Sampford et al., 2006).

The prevalence of corruption is usually measured by perception indices presenting subjective opinions on the perceived level of corruption. ${ }^{2}$ Those estimates might be influenced by general public views, reports on recent corruption scandals, cultural or historical heritage, and are rarely supported by corruption experiences of the respondents. Complementary to measuring corruption perceptions, up-to-date surveys on corruption experiences provide the most effective tool to get deeper insight into the scope and modes of corrupt activities. Information on corruption experiences is valuable, yet would not provide reliable data on the volume of actual corruption transactions and corresponding financial losses. Estimates reached by extrapolating reported corruption experiences to the whole sector, society group or nation are not accurate since the potential underreporting problem might significantly affect results. Further, the real extent of corruption is not measurable because there is no evidence on how many corrupt actions committed have ever been revealed. However, survey data on corruption experiences might serve as a valuable indication of sources and modes of corruption, thus enabling anti-corruption strategies to be more precisely targeted and therefore more effective.

This clear objective of exploring both corruption experiences and corruption perceptions has boosted the number of corruption surveys conducted in the last decade (Treisman, 2007). Quantitative measurement of corruption experiences in surveys has become popular since more sophisticated and ap- 
DRUŠ. ISTRAŽ. ZAGREB GOD. 21 (2012), BR. 2 (116),

STR. $291-313$

BUDAK, J., RAJH, E.: CORRUPTION SURVEY... propriate survey methodologies have been applied (Reinikka and Svensson, 2006). However, the methodology of surveying corruption is still undergoing critiques, calling for further improvements. One of the major issues is the problem of overestimating perceived corruption prevalence opposed to the underreported corruption experiences. Underreporting behavior is broadly explained within the cost-benefit theoretical mo$\mathrm{del}$, and research studies mostly discuss the problem of underreporting in the context of shadow economy (Schneider and Enste, 2002). There is a body of literature on the factors that deter people from officially reporting corruption (Zipparo, 1998), yet very few studies on how to deal with this problem in surveying corruption experiences are available. The recent study of Jensen et al. (2007) provides a new concept of gathering useful information from nonresponse and false response to corruption-related questions in firm-level corruption surveys, while Reinikka and Svensson (2006) have discussed how to overcome misreporting problems in surveying educational and health institutions and firms. Besides the general lack of literature on this topic, the above-mentioned contributions are related to surveying firms and institutions, and to our knowledge, no such analysis has been made for surveying the corruption experiences of the general public. For the latter, it would be interesting to explore the reasons behind personal reluctance to report corruption.

Citizens in Croatia are aware that living in an information society in some segments leads "towards a surveillance society" (Radovan, 2006). This subjective notion, combined with memories of the past undemocratic regime, could seriously prevent respondents from reporting corruption experiences. Citizens are very much aware that all data and information collected will be electronically processed and kept for records. All gathered information could be (mis)used for further surveillance, manipulation and even prosecuting people (Radovan and Jugo, 2006). Studies have shown that U.S. citizens have concerns about privacy and confidentiality even in returning census forms (Singer et al., 2003). A low response rate can skew the findings of surveys dealing with sensitive issues, such as opinion research about surveillance and privacy (Haggerty and Gazso, 2005). Survey reporting on corruption is particularly sensitive because both sides participating in corruption (bribe-givers and bribe-takers) are subject to criminal prosecution. ${ }^{3}$ If reported a posteriori, i.e., once a corruption transaction is realized, there might be fear of consequent surveillance to gather more evidence on corrupt officials or even investigation and prosecution. This would not only induce the underreporting of corruption but also increase the refusal rate and thus bias the survey results. 
DRUŠ. ISTRAŽ. ZAGREB GOD. 21 (2012), BR. $2(116)$

STR. $291-313$

BUDAK, J., RAJH, E. CORRUPTION SURVEY...
Theoretical thought underpins trust in the institutions as a key component of social capital (Nooteboom, 2007; Berggren and Jordahl, 2006). As public opinion is a product of social capital and institutional set-up, a notable portion of public opinion about corruption and other forms of crime is being formed according to citizens' confidence in the institutions that should ensure their security. A part of the survey collects data on sharing information about corruption experiences and reporting them. It provides a unique source of information about real and perceived trust in institutions responsible for dealing with corruption. Public awareness about corruption represents an important pillar of anti-corruption efforts. If the attitudes of citizens are not clearly in line with the promoted zero tolerance towards corruption, room is made for acts of corruption to emerge.

Several studies on trust in institutions in Croatia (Baloban and Rimac, 1999; Štulhofer, 2004) refer to the past period (1997 and 1995 to 2003, respectively). In light of the increased number of corruption scandals and intensified efforts to combat corruption in Croatia, one could suppose that general public views on both corruption and institutions have changed. Further, previous research dealt either with a general sense of trust or trust in various kinds of institutions, while there was no particular focus on anti-corruption agencies and institutions.

Notwithstanding that both informal and formal institutions ${ }^{4}$ shape public attitudes towards corruption, in our empirical research we have collected data on trust in formal institutions (agencies enforcing legislative anti-corruption measures). The surveyed corruption experiences refer to bribes citizens gave to public employees in money, goods or counter-favors above the official cost of the public service. Our focus on these aspects of corruption and associated trust in institutions was driven by the conceptual development of the survey methodology, which is described in the following section.

\section{METHODOLOGY OF SURVEYING CORRUPTION IN CROATIA}

Assessing corruption perceptions and corruption experiences was part of the Survey on use of public services and public integrity for which the pilot testing was conducted in Croatia in June 2010. The net sample size for the pilot was 150 respondents of age 18 to 64 . The pilot survey was conducted by face-to-face interviews in three different regions of Croatia (urban and rural areas of Zagreb, Osijek and Split). Towns were divided in homogenous areas e.g. center, first ring. The sample was defined by random selection of addresses/households and random selection of respondents. The interviewer had to choose 
DRUŠ. ISTRAŽ. ZAGREB GOD. 21 (2012)

BR. 2 (116),

STR. $291-313$

BUDAK, J., RAJH, E.: CORRUPTION SURVEY...

\section{(1) TABLE 1}

Comparison of population and sample characteristics the member of the household to be interviewed with the help of the birthday key.

The main survey followed in July and August 2010 on a nationally representative sample of 3005 Croatian citizens aged 18 to 64 . We employed the same methodology as in the pilot survey. A nationally representative sample is made on a two-way stratification by six regions (formed by grouping counties) and four types of settlements. Four types of settlements differ according to size, and correspond to the local administrative system in Croatia. Settlements up to 10,000 inhabitants have the status of municipality, and settlements above 10,000 inhabitants have a status of town. The sample allocated to each stratum is proportional to the population living in each stratum. Towns and villages selected in the sample are further divided into areas and in each area starting points for walks were randomly selected. 196 starting points were used for the interviewer's walks. During the fieldwork, based on precisely defined standard procedures, the sample is further defined by: random selection of addresses/households and random selection of respondents (household member of age 18 to 64 with the help of birthday key). Double-check assurance of data collection from the nationally representative sample is provided by noting to the interviewers provisional quotas required (by sex and age brackets for each of 196 interviewers' starting points). Percentages in each stratum in total population (according to Census 2001, for age group 18-64) and those achieved in the sample are closely corresponding (Table 1).

\begin{tabular}{|c|c|c|c|}
\hline & & Population (\%) & Sample $(\%)$ \\
\hline Region & $\begin{array}{l}\text { Zagreb } \\
\text { North Croatia } \\
\text { Slavonia } \\
\text { Lika, Kordun, Banovina } \\
\text { Istria, Hrvatsko Primorje, Gorski Kotar } \\
\text { Dalmatia }\end{array}$ & $\begin{array}{r}25.3 \\
15.7 \\
19.7 \\
8.3 \\
11.9 \\
19.1\end{array}$ & $\begin{array}{r}24.9 \\
16.1 \\
19.4 \\
9.0 \\
11.8 \\
18.8\end{array}$ \\
\hline Settlement Size & $\begin{array}{l}\text { Up to } 2.000 \\
2.001-10.000 \\
10.001-100.000 \\
\text { More than } 100.000\end{array}$ & $\begin{array}{l}39.5 \\
16.3 \\
21.4 \\
22.8\end{array}$ & $\begin{array}{l}38.5 \\
16.0 \\
21.5 \\
24.0\end{array}$ \\
\hline Gender & $\begin{array}{l}\text { Male } \\
\text { Female }\end{array}$ & $\begin{array}{l}49.6 \\
50.4\end{array}$ & $\begin{array}{l}47.4 \\
52.6\end{array}$ \\
\hline Age & $\begin{array}{l}18-30 \\
31-50 \\
51-64\end{array}$ & $\begin{array}{l}27.9 \\
45.9 \\
26.2\end{array}$ & $\begin{array}{l}28.0 \\
44.5 \\
27.6\end{array}$ \\
\hline
\end{tabular}

Source: For population, Census 2001. 
DRUŠ. ISTRAŽ. ZAGREB GOD. 21 (2012), BR. 2 (116)

STR. $291-313$

BUDAK, J., RAJH, E.: CORRUPTION SURVEY..

(1) TABLE 2

Fieldwork control statistics
On average, interviewers did 1.12 visits per household and spent 33.47 minutes with respondent for successfully finished interviews. In order to achieve a nationally representative sample, the net sample size was set to 3000 respondents, which gives the standard error of estimate of around a low $1 \%$. As the fieldwork had to run until the target number of 3000 filled questionnaires was reached, we achieved 3005 interviews and a posteriori calculated the response rate of $50.2 \%$.

The first step in convincing respondents to participate in the survey was to secure overall confidence in the project. A cover letter used in the pilot as well as in the main survey pointed out the distinguished partners in the project (legally neutral international institutions and local research experts). Further, respondents were informed that the data collected would be treated confidentially and the respondents would remain anonymous. Their personal data were collected on the separate paper sheet. Respondents optionally provided their contacts to be used for the fieldwork back-check (Table 2).

\begin{tabular}{llrr}
\hline & & $\mathrm{N}$ & $\%$ \\
\hline Interview subject to Back-check / Control & Yes & 960 & 31.9 \\
& No & 2045 & 68.1 \\
& Back-check in person & 60 & 6.3 \\
& Back-check by telephone & 900 & 93.8
\end{tabular}

In the introductory letter, the project was presented as an effort to collect information on citizens' experiences with public services. The aim of the survey was to explore public integrity as a whole and to examine experiences of crime victimization. As corruption was indeed only a part of the Survey on use of public services and public integrity, it allowed us to not mention corruption explicitly in the pilot survey cover letter. Disclosing the entire purpose of the survey, although legitimate and meaningful, could have raised the concerns of the respondents: "The objective is to collect information that will assist the Government... in fighting crime, inter alia, by combating corruption." Respondents however could avoid sensitive corruption experience questions in the related parts of the survey ("No answer" option provided).

This potential obstacle was resolved by raising the competence of interviewers in clarifying and elaborating on how the collected information would be kept and processed. The risk of personal data being misused was minimized by using separate locations for data processing and analysis. As contracted, the market research agency conducting the survey on site should deliver an electronic database, but the original 
DRUŠ. ISTRAŽ. ZAGREB GOD. 21 (2012)

BR. $2(116)$

STR. $291-313$

BUDAK, J., RAJH, E.: CORRUPTION SURVEY... questionnaires should not be made available to the institution reporting the aggregate survey results. Regardless of which side the initiative comes from (citizen offering a bribe or public official asking for a bribe), both sides involved in a corrupt activity legally are considered to have committed a criminal act. A final measure of security assurance involved checking with the anti-corruption agencies in Croatia that there was no legislative possibility of evidence being requested regarding the personal accounts of corruption in the survey.

In designing the questionnaire, one had to consider that the respondents would be aware that their participation in corrupt transactions might discredit their integrity. Therefore the wording of the questions about personal corruption experiences implied that the initiative did not come from the respondents (e.g., "... you had to give a gift", "... you had to make such an extra payment"). This solution was expected to relieve the sense of guilt and consequently to encourage respondents to provide true answers to sensitive questions.

The questionnaire was structured in eight sections. Section 1 collected opinions on selected topics regarding the problems facing Croatia today, perceptions on corruption prevalence and attitudes towards corruption phenomena. Experiences with public services and citizens' satisfaction in contacts with various civil servants and public officials were examined in section 2. Bribery experiences were questioned in section 3 . Specifically, respondents were asked about their recent personal involvement in corruption acts, types of bribery and related purpose. For those who had had corruption experiences in the last 12 months, we were interested to know whether they had reported the cases of corruption and what the outcomes were. Other practices such as corruption related to elections or public sector hiring practices as well as opinions on the integrity of public officials were surveyed in section 4 . Reasons for (not) reporting corruption and trust in institutions were explored in section 5 of the questionnaire. Section 6 represented a victimization survey, asking about experiences of car theft, burglary, personal theft, assault, theft, and robbery. General information on the respondent's sex, age, education, occupation, and income was collected in section 7 . The last section, section 8 , contained an interview evaluation by the interviewer, indicating the respondent's remarks during or after the interview. Given the described questionnaire structure, we have selected those questions and answers that give us insight into confidentiality issues of the survey and reporting corruption. The original formulations of the questions relevant for this study are listed in the Appendix, with a reference of the question number in brackets of the text. 


\section{EMPIRICAL ANALYSIS RESULTS}

\section{Pilot Survey Solutions to Confidentiality Issues}

Already in the pilot survey, an important methodological concern was resolved as no major quitting problem had been observed in the corruption experience section of the questionnaire. One could suppose at that point that the respondents felt confident due to the carefully developed questionnaire and professionally trained interviewers.

At the end of the pilot interview, respondents had an opportunity to give blank remarks on the survey. Out of a total of 150 pilot survey respondents, 16 percent gave additional remarks. Most of the remarks were concerns expressed regarding the future use of the results, followed by concerns regarding the confidentiality of the survey. Few respondents were worried about the potential misuse of the victimization part of the survey data (whether information on home security would be abused by burglars), indicating that a possible leakage of data collected has been perceived as a problem. The pilot testing results conclusively supported the survey questionnaires and methodology developed. No problems arose related to the sensitive questions on corruption experiences, and some confidentiality issues proved to be irrelevant for the response rate. Since no differences have been observed in responses by face-to-face interview vs. partial self-administration of the questionnaire, this particular confidentiality issue could be disregarded.

Over 17 percent of respondents claimed they had recent corruption experiences, and provided further details on those transactions. We proceed to the empirical analysis of survey results on reporting corruption experiences and related trust in the institutions in Croatia.

\section{Survey Results on Reporting Corruption}

In order to better understand the current situation and to frame the context of the survey, several introductory questions were posed. According to the respondents, unemployment (26 percent) and poor performance of the Government (24 percent) are considered to be the major problems that Croatia is facing today, which is understandable given the economic crisis [Q1.1]. Corruption is a major problem in Croatia for 24 percent of respondents and according to public perceptions there are no signs of improvement. On the contrary, 44 percent of respondents think the level of corruption has remained the same, while 47 percent believe corruption has increased in the last three years [Q1.8]. 
DRUŠ. ISTRAŽ. ZAGREB GOD. 21 (2012) BR. $2(116)$

STR. $291-313$

BUDAK, J., RAJH, E.: CORRUPTION SURVEY...

(1) TABLE 3

Prevalence of bribery based on respondents who had contact with public employees in the last 12 months $(\mathrm{N}=2592)$ [Q3.1], in \%
Although the perceived level of corruption is still rather high, the actual experiences of Croatian citizens show promising outcomes. 86 percent of respondents who had contacts with public employees in the last 12 months [Q2.1] did not have to give any gift, counter-favor or extra money to a civil servant or public official [Q3.1] (Table 3). Of those who had recent corruption experiences, in 92 percent of the cases respondents claimed they had given such a gift to doctors and/or nurses [Q3.2]. In contacts with health sector employees it is generally considered a custom for the patient to offer a small thank-you gift (a packet of coffee or a box of chocolate), and such gifts usually do not substantially determine the accessibility of health services or their quality. To a lesser extent bribes were given to police officers (30 percent of corruption cases) and for car registration (14 percent). It is worth noticing that in most of those cases the incentive came from the bribe-giver [Q3.8] who voluntarily offered a bribe to avoid fines, for example. Negligible corruption experiences have been reported in contacts with custom officers, public utility services, tax authorities, local government, social protection services, teachers and professors, judges and prosecutors, or cadastre officers (5 to 20 individual cases per public service sector) [Q3.2].

Yes No remember

Q3.1. Please consider all the contacts you had with a civil servant/ public official in the last 12 months: did it happen that you had to give to any of them a gift, a counter-favor or some extra-money, including through an intermediary (with the exclusion of the correct amount of official fees)?

From the selected questions and the distribution of answers, one could tell that reporting on corruption experiences in our survey posed no problem to the respondents in general. Yet, of 296 of the total respondents who had a recent corruption experience, only 2 percent reported the case formally to the police, State Attorney's Office / USKOK, anti-corruption body or ombudsperson.

When asked why they did not report the personal corruption experience to relevant institutions [Q3.14], half of the respondents stated they had gained benefits from the bribe or had given the bribe as a sign of gratitude (Figure 1). Further, 24 percent of the respondents do not believe that anything useful would be done upon reporting. This last statement is supported by the bitter experience of several respondents who have submitted reports on corruption experiences, but with no results. Out of the total six citizens' reports submitted on 
DRUŠ. ISTRAŽ. ZAGREB GOD. 21 (2012), BR. 2 (116)

STR. 291-313

BUDAK, J., RAJH, E CORRUPTION SURVEY.

$\rightarrow$ FIGURE

Reasons for not reporting personal corruption experience $(\mathrm{N}=290$; only respondents who had a corruption experience in the last 12 month but did not report it; [Q3.11; Q 3.12]) corruption experiences, five haven't had any follow-up by officials [Q3.13]. Moreover, a fear of reprisal was a reason for worry for 3 percent of respondents [Q3.14].

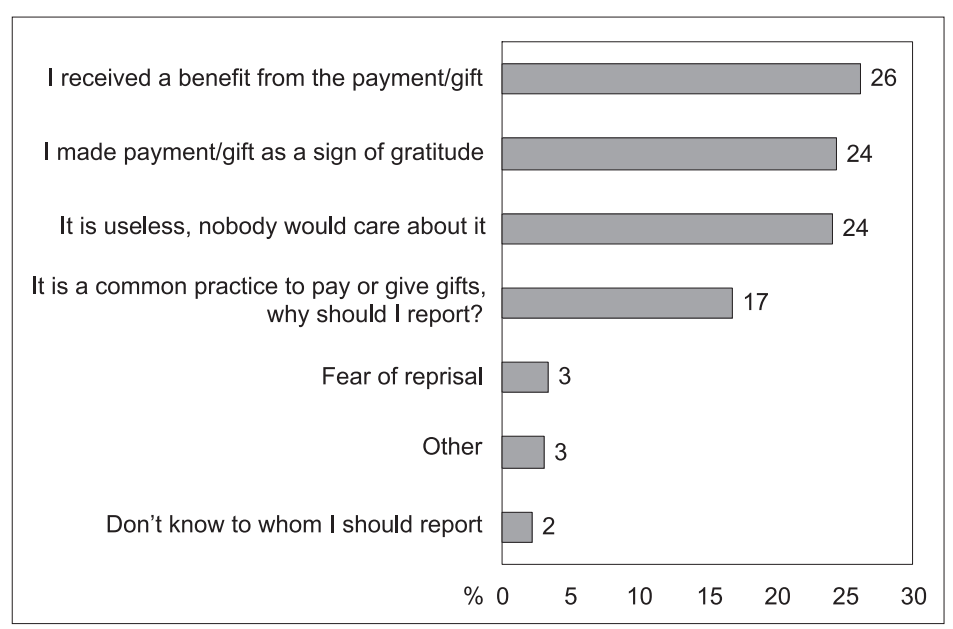

Besides a very high level of opportunism, those statements indicate there might be a substantial distrust in the institutions regarding their willingness and efficiency to fight corruption. However, some people tend to share their corruption experiences informally, either because they feel as victims or to advise someone to give a bribe as a way to solve a problem. 71 percent of participants in corruption acts did talk about them with their family or friends. None of them talked to NGOs and only one person reported the case of corruption to the media. 29 percent did not talk about it to anybody [Q3.15]. Although their reasons remain unknown, assumed reasons such as feeling embarrassed, concern of moral judgement, and fear of persecution, public investigation or criminalization might deter people from reporting corruption, formally and informally.

\section{Public Views on Reporting Corruption and Trust in Institutions}

Better insight into the aforementioned issues is provided by the survey results on reporting hypothetic corruption experiences. Regardless of whether respondents had personal corruption experiences or not, their views about reporting corruption strongly support two worrying assumptions. More than half of all respondents in the total sample think that people who report corruption are likely to regret it (55 percent of respondents fully agree and agree), and that sometimes corruption is the only way to get things done (53 percent). In line with the prevailing opinion, the simple majority of respondents disagrees or fully disagrees with the three other statements (Table 2) [Q5.1]. 


\begin{tabular}{|c|c|c|c|}
\hline Statement & Attitude & $\begin{array}{l}\text { Fully agree } \\
\text { ind agree }(\%)\end{array}$ & $\begin{array}{c}\text { Disagree and } \\
\text { fully disagree }(\%)\end{array}$ \\
\hline $\begin{array}{l}\text { People who report corruption } \\
\text { are likely to regret it }\end{array}$ & Intimidated & 55 & 40 \\
\hline $\begin{array}{l}\text { Sometimes corruption is the only way to get } \\
\text { things done }\end{array}$ & Affirmative & 53 & 44 \\
\hline $\begin{array}{l}\text { There is no point in reporting corruption } \\
\text { because nothing useful will be done about it }\end{array}$ & Resigned & 47 & 51 \\
\hline Nobody knows where to report corruption acts & Not interested & 44 & 52 \\
\hline $\begin{array}{l}\text { It is common practice to pay or give gifts, } \\
\text { why should I report? }\end{array}$ & Dismissive & 31 & 67 \\
\hline
\end{tabular}

\section{(1) TABLE 4}

General attitudes on reporting corruption $(\mathrm{N}=3005$; omitted values refer to "I don't know" answers $(4.5$ percent); [Q5.1])
Respondents' attitudes towards each of the statements about reporting corruption are classified in five descriptive categories (intimidated, affirmative, resigned, not interested, and dismissive). If it is the widespread perception of the population that people reporting corruption would most likely regret it afterwards, one could assume that citizens sharing this opinion would not report corruption. Although the survey data did not enable us to get into the background reasons for an "intimidated" attitude, one could assume that the regret to which the respondents were referring is related to nuisance (such as media exposure, complicated follow-up procedures, formal investigation, and testimony at court) and/or fear (of reprisal or criminalization).

An "affirmative" attitude is shared by 53 percent of respondents who see corruption as a mechanism to ensure the delivery of public services. Corruption functioning as a grease in the wheel in conditions of inefficient public administration has been well examined in the literature, since the early works of Leff (Leff, 1964). However, there is a wide consensus about the adverse effects of corruption prevailing (Mauro, 1995; Tan$\mathrm{zi}, 1998)$. Fighting the greasing wheel of corruption is related to improving public administration efficiency, which is the focus of interest of any good governance policy. In the context of this study, however, respondents would not report corruption because they either approve it as a state of fact or they feel helpless in contacts with a growing bureaucracy. Corruption practices revealed by the survey are in favor of the first statement. Corruption cases surveyed revealed remarkable opportunism of bribe-givers (bribes were given as a sign of gratitude, to by-pass the costs, to avoid fines, to get extra benefits, etc.). Corruption acts initiated by the bribe-givers explain the affirmative attitude towards corruption as a tool to "resolve issues". 
DRUŠ. ISTRAŽ. ZAGREB GOD. 21 (2012), BR. $2(116)$

STR. $291-313$

BUDAK, J., RAJH, E.: CORRUPTION SURVEY..
The majority of respondents disagreed with the last three statements on reporting corruption (Table 4). The largest majority of respondents reject the statement that corruption is not worth reporting because bribing is common practice. The counter-opinion (shared by 31 percent of respondents) might look similar to the interest-driven "affirmative" view, but the "dismissive" attitude is substantially different. Whereas the former approves committing bribes for the personal gain of the bribe-giver, the latter might consider gifts a harmless and trivial common practice. This explanation is supported by the survey data on the practice of giving small thank-you gifts to doctors and nurses. For the encouraging majority of respondents who would not tolerate giving bribes or gifts and consequently would report such immoral behavior, zero tolerance to corruption is observed. This might be attributed to the recently intensified combat against corruption in Croatia.

About half of the respondents are in favor of the statements that (i) corruption is not worth reporting because nothing useful will be done about it, and (ii) people are not informed about where to report cases of corruption. These observations call for careful rethinking on the role and efficiency of the official institutions. People in Croatia might be resigned and disappointed with the course of the combat against corruption. As large corruption scandals were revealed, the investigation and prosecution that followed may not be seen as efficient and fast enough from the public point of view. The evidenced "missing information on where to report corruption" reflects people's ignorance and lack of interest to report corruption. Citizens do have the possibility to report corruption to a number of institutions. They can liberally choose whether to contact official anti-corruption agencies via phone, e-mail, fax, mail, in person, or anonymously. Such contact numbers are provided by the Ministry of Justice, Ministry of the Interior, USKOK Office, ${ }^{5}$ Transparency International Croatia, tax authorities, and many others. ${ }^{6}$ Reporting corruption to the police is within the reach of every Croatian citizen.

When asked which institutions they would report potential corruption to in the future [Q5.2], the respondents' first choice was the police (28 percent), followed by the State Attorney's Office and USKOK (16 percent). Since USKOK is well known as a special office for fighting corruption and organized crime within the State Attorney's Office, the police and USKOK seem to be the natural choices as official institutions to deal with reported corruption. 14 percent of total respondents would report the case to the supervisor of the corrupt public official, thus expressing their confidence in internal anti-corruption procedures rather than in official crime-fighting institutions (Figure 2). 
DRUŠ. ISTRAŽ. ZAGREB

GOD. 21 (2012)

BR. 2 (116),

STR. 291-313

BUDAK, J., RAJH, E.: CORRUPTION SURVEY...

\section{FIGURE 2}

First choice institutions to report potential corruption experience in the future, $N=3005$

(1) TABLE 5

Experience of victimization $(\mathrm{N}=3005)$, in \%

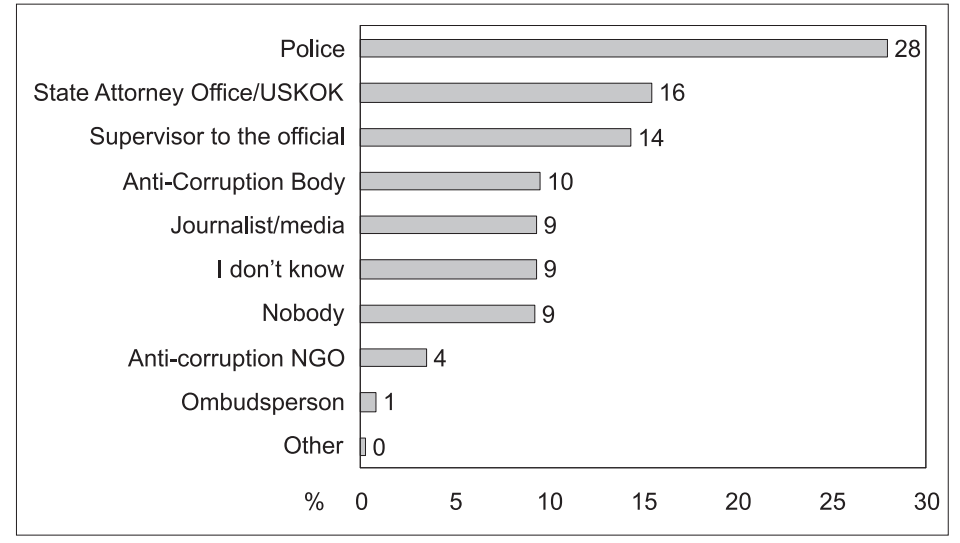

In the victimization part of the survey, respondents described their recent exposure to various types of crime other than corruption. In the last five years, most of the crimes referred to personal theft (10 percent) [Q6.17], assaults or threats (7 percent) [Q6.21], burglary (4 percent) [Q6.7], robbery (3 percent) [Q6.11], and car theft (1 percent) [Q6.2] (Table 5).

Over the past five years (since July 2005)

Don't Don't

Yes No remember have car

Q6.2 ...have you or other members of your household had any of their cars/vans/trucks stolen when nobody was in the vehicle?

Q6.7 ...did anyone actually get into your house or flat without permission and steal or try to steal something?

I am not including here thefts from garages, sheds or lock-ups.

Q6.11 ...has anyone stolen, or tried to steal, something from you by using force or threatening you?

Q6.17 There are different types of theft of personal property, such as pick-pocketing or theft of a purse, wallet, clothing, jewelry, mobile phone or sports equipment. This can happen at one's work, at school, in a pub, on public transport, on the beach, or in the street. ...have you personally been the victim of any of these incidents?

Q6.21 ...apart from the incidents just covered, have you been personally attacked or threatened by someone in a way that really frightened you either at home or elsewhere, such as in a pub, in the street, at school, on public transport, or at your workplace?

As shown in Figure 3, Croatian citizens are willing to report those types of crime to the police. Car theft was always reported to the police, probably for insurance and deregistration needs [Q6.6]. Burglary [Q6.10], and robbery [Q6.16], were 
DRUŠ. ISTRAŽ. ZAGREB GOD. 21 (2012), BR. 2 (116)

STR. 291-313

BUDAK, J., RAJH, E. CORRUPTION SURVEY.

2 FIGURE 3 Reporting rates per type of crime in croatia (bribery experience refers to cases in the last 12 months, reported to official institutions; other forms of crime refer to experiences in the last 36 months reported to the police) reported in about two thirds of the cases, most likely when significant damage occurred. Half of the total personal theft cases were reported [Q6.20], presumably depending on the loss. Assaults and threats were reported to a smaller extent [Q6.24].

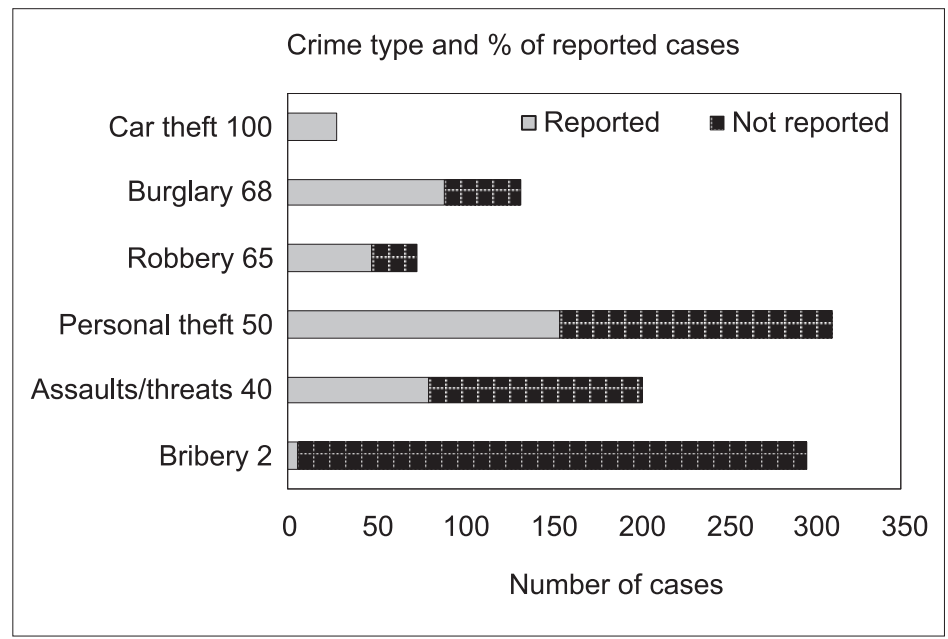

This research evidenced a strong reluctance of citizens to report corruption to official institutions for various (more or less) rational reasons. The police and USKOK are perceived as the most trustworthy institutions to report corruption in Croatia, and the police stands as the primary institution to contact when reporting other forms of crime in Croatia.

\section{CONCLUDING REMARKS}

Corruption is widespread in Croatia and curbing corruption is one of the major tasks of the Croatian government on its path of accession to the European Union (Budak, 2006). Surveying Croatian citizens about the integrity of public services as well as examining public opinions on perceptions and corruption experiences are expected to strengthen anti-corruption efforts.?

Therefore it is of the utmost importance not only to conduct surveys, but to convince respondents - ordinary citizens - to provide honest and sincere answers to sensitive questions. This issue has been identified in the existing empirical research literature on corruption (Treisman, 2007), but has not been addressed in the context of misuse of personal data of respondents and taking into account the potential risk of surveillance. In this regard, assessing the risk of data leakage and misuse that could lead to greater underreporting of corruption experiences in surveys was for us rather limited. The confidence in ICT technologies used in the survey process leaves room for future research as well. 
DRUŠ. ISTRAŽ. ZAGREB GOD. 21 (2012)

BR. $2(116)$

STR. $291-313$

BUDAK, J., RAJH, E.: CORRUPTION SURVEY...
It seems that the described methodology of survey did not influence the possible underreporting of corruption experiences. Of course, one cannot ever tell if and to what extent the corruption experiences have been underreported or drive conclusions on the real corruption numbers. A major concern of respondents, even in limited scope, has been expressed regarding the final and true purpose for which the data will be used afterwards. This intuitively indicates a lack of trust in the institutions rather than fear of being surveilled. It also reveals (but to a modest extent) a fear of whether the personal data provided in the survey would remain anonymous, although the anonymity of the respondents was protected more than requested by standard market research procedures.

Survey data provided insight into Croatian citizens' everyday experiences in contacts with the public sector. Our unique focus on corruption experiences and related reporting issues portrayed to some extent whether people in Croatia feel secure in this cumbersome area and properly protected by the responsible institutions. The significant reluctance to report corruption observed in Croatia can be mainly attributed to the very high level of opportunism and lack of trust in the institutions. About two thirds of respondents with corruption experiences think that corruption is a standard form of behavior, and the simple majority of all respondents consider it pointless to report corruption to official institutions. The main scope of this paper is explaining specific methodological issues in surveying corruption. The research does not provide an indepth empirical analysis of the micro-data collected in the survey. Although further analysis is needed to derive comprehensive anti-corruption measures, the findings of this study offer some policy recommendations.

Policy implications to combat corruption should primarily be targeted at strengthening anti-corruption awareness, i.e., changing public attitudes. In eliminating administrative corruption, it is of the utmost importance to convince citizens that even a small thank-you gift should be considered corruption, and that any form of corrupt activity seriously distorts accessibility to public services. Administrative "petty" corruption goes hand in hand with "grand" political corruption and they interchangeably form a vicious circle of systemic corruption in the society. Carefully designed public campaigns, promoting current efforts of anti-corruption institutions to the media and citizens, and more widely publicizing corruption hotlines and addresses for reporting corruption (in particular in rural regions and among elderly people), would contribute to the success of anti-corruption efforts and to building public trust in the institutions. Strict implementation and monitoring of ethical codes of conduct in public administra- 
tion would benefit the eradication of administrative corruption as well. Once citizens witness more corruption-free public services, their perceptions of the overall corruption prevalence in Croatia will consequently become lower.

\section{APPENDIX}

\section{The questions relevant for this study}

Q1.1 In your opinion, what are the most important problems that Croatia is facing today? (Please mark up to three items, ranking from 1 (most important) to 3 (least important))
Performance of Croatian Government
Building a functioning public administration
Corruption
Condition of infrastructures (transport, communication, energy, etc.)
Poverty / Low standard of living
Unemployment
Poor performance of education system
Environmental degradation
Crime and insecurity
Relations between ethnic groups
$\square$ Other (please specify: ...)

Q1.8 Compared to 3 years ago, do you think that the overall level of corruption in Croatia has increased or decreased? (Please mark one answer only)

$\square$ Increased

$\checkmark$ Stable

$\square$ Decreased

Q2.1 In the last 12 months, have you ever had contacts with any of the following civil servants/public officials, including through an intermediary, for example to use a public service, to ask for information/assistance, to request a document, or while processing an administrative procedure? (Please mark each row)

Police officers

Judges/Prosecutors

Cadastre officers

Tax/revenues officers

Customs officers

Public utilities officers (electricity, telephone, etc.)

Municipal or provincial officers

Doctors (from public sector)

Nurses (from public sector)

Teacher/Professors (from public sector)

Social protection agency/ministry officers (pensions, allowances, etc.)

Car registration/driving license agency officers

Municipal or provincial elected representatives (mayor, town councils, etc.)

Members of Parliament

Members of Government

Non-government organizations (NGOs)

Embassy/consulate officers of foreign countries

Other public official (....

\section{Contact}

Yes $\square$ No $\square$

Yes $\square$ No $\square$

Yes $\square$ No $\square$

Yes $\square$ No

Yes $\square$ No $\square$

Yes $\square \mathrm{No} \square$

Yes $\square$ No $\square$

Yes $\square$ No $\square$

Yes $\square \mathrm{No} \square$

Yes $\square \mathrm{No} \square$

Yes $\square \mathrm{No} \square$

Yes $\square$ No $\square$

Yes $\square$ No $\square$

Yes $\square$ No $\square$

Yes $\square$ No $\square$

Yes $\square \mathrm{No} \square$

Yes $\square$ No $\square$

Yes $\square$ No $\square$ 
Q3.1 Please consider all the contacts you had with a civil servant/public official in the last 12 months: did it happen that you had to give to any of them a gift, a counter-favor or some extra-money, including through an intermediary (with the exclusion of the correct amount of official fees)? (Please mark one answer only)

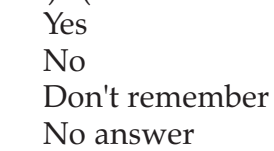

Q3.2 To whom and how many times did you have to give a gift, any goods or some extra-money in the last 12 months, including through an intermediary (with the exclusion of the correct amount of official fees)? (Please mark all that apply, and specify number of occasions)

Police officers

Payment/gift was given

Judges/Prosecutors

Yes $\square$ No $\square$

Cadastre officers

Yes $\square$ No $\square$

Tax/revenues officers

Yes $\square$ No $\square$

Customs officers

Yes $\square$ No $\square$

Public utilities officers (electricity, telephone, etc.)

Yes $\square$ No

Municipal or provincial officers

Doctors (from public sector)

Nurses (from public sector)

Teacher/Professors (from public sector)

Social protection agency/ministry officers

Car registration/driving license agency officers

Municipal or provincial elected representatives (mayor, town councils, etc.)

Members of Parliament

Members of Government

Non-government organizations (NGOs)

Embassy/consulate officers of foreign countries

Other public official ..)

Yes $\square$ No $\square$

Yes $\square$ No

Yes $\square$ No

Yes $\square \mathrm{No} \square$

Yes $\square$ No

Yes $\square$ No $\square$

Yes $\square$ No $\square$

Yes $\square$ No $\square$

Yes $\square$ No $\square$

Yes $\square \mathrm{No} \square$

Yes $\square$ No $\square$

Yes $\square$ No $\square$

Q3.8 Last time that you had to make such extra payment or gift, how did you understand that an extra payment or gift was expected? (Please mark only one answer)

$\square$ Explicit request from the public official

$\square$ The public official made you understand that a payment was expected

A third person requested the extra payment

Nobody asked for it, I did it to facilitate/accelerate the procedure

Don't remember

Q3.11 Last time that you had to make such extra payment or gift, did you report it to any official authority/institution (e.g. police, prosecutor, anti-corruption agency, etc.)? (Please mark only one answer)

$\square$ Yes
$\square$ No

Q 3.12 If Yes, whom did you report to? (Please mark only one answer)

Police

$\square$ State Attorney Office/USKOK

Anti-Corruption Agency

$\square$ Ombudsperson

$\square$ Same agency/institution of the officer requesting bribe, please specify:

$\square$ Other office, please specify: ...)

I don't know 
Q3.13 What happened after your reporting? (Please mark only one answer)

$\square$ A formal procedure was started against the officer

$\square$ The problem was solved informally and I was given back the money/gift

$\square$ I was advised not to go ahead with my report

$\square$ There was no follow-up to my report

$\square$ Don't know

Q3.14 If Not, why didn't you report? (Please mark only one answer)

$\square$ It is a common practice to pay or give gifts, why should I report?

$\square$ It is useless, nobody would care about it

$\square$ Don't know whom I should report to

$\checkmark$ Fear of reprisal

$\square$ I received a benefit from the payment/gift

$\square$ I made payment/gift as a sign of gratitude

Other reason, please specify:

Q3.15 Last time that you had to make such extra payment or gift, did you talk about it with: (Please mark all that apply)

$\square$ Friend or relative of yours

$\checkmark$ Journalist/media

$\square$ NGO

Other person, please specify:

$\square$ No, with nobody

Q5.1 To what extent do you agree or disagree with the statements below on reporting corruption? (Please mark each row: Fully agree; Agree; Disagree; Fully disagree, Don't know)

$\square$ It is a common practice to pay or give gifts, why should I report

$\square$ There is no point in reporting corruption because nothing useful will be done about it

$\square$ People who report corruption are likely to regret it

$\square$ Sometimes corruption is the only way to get things done

$\square$ Nobody knows where to report on corruption acts

Q5.2 If in the future you had to report a case where you were requested to pay some extra money or give a gift to a public official, who would you report it to? (Please mark up to three items, ranking from 1 (most important) to 3 (least important)).

$\square$ Supervisor to the official (in the same organization of the officer requesting the bribe)

$\checkmark$ Police

$\square$ State Attorney Office/USKOK

Anti-Corruption Body

Ombudsperson

Journalist/media

Anti-corruption NGO

$\square$ Other person, please specify: (...............)

$\square$ Nobody

$\neg$ I don't know

Q6.2 Over the past five years (since July 2005), have you or other members of your household had any of their cars/vans/trucks stolen when nobody was in the vehicle?

$\square$ Yes

$\square$ No

$\square$ Don't remember 
Q6.7 Over the past 5 years (since July 2005), did anyone actually get into your house or flat without permission and steal or try to steal something? I am not including here thefts from garages, sheds or lock-ups.

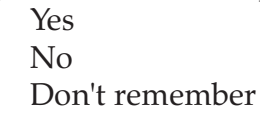

Q6.11 Over the past 5 years (since July 2005), has anyone stolen, or tried to steal, something from you by using force or threatening you?

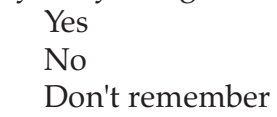

Q6.17 There are different types of theft of personal property, such as pick-pocketing or theft of a purse, wallet, clothing, jewellery, mobile phone or sports equipment. This can happen at one's work, at school, in a pub, on public transport, on the beach, or in the street. Over the past 5 years (since July 2005), have you personally been the victim of any of these incidents?
$\square$ Yes
$\square$ No
Don't remember

Q6.21 Apart from the incidents just covered, have you over the past five years (since July 2005) been personally attacked or threatened by someone in a way that really frightened you either at home or elsewhere, such as in a pub, in the street, at school, on public transport, or at your workplace?
$\square$ Yes
$\square$ No
$\square$ Don't remember

Q6.6, Q6.10, Q.6.16, Q6.20, Q6.24 The last time did you or anyone else report the incident to the police?
$\square$ Yes
$\square$ No
$\square$ Don't know

\section{NOTES}

1 This research stemmed from the project Household survey on experience of corruption and other forms of crime in Croatia, which was based on a grant agreement between the Institute of Economics, Zagreb and UNODC. The views and results presented in this paper, however, are the authors' responsibility only.

2 Two widely used corruption perception measures are Corruption Perceptions Index of Transparency International (http://www.trans parency.org) and Control of Corruption as one of the Worldwide Governance Indicators (developed by the World Bank Institute, http://www.worldbank.org).

3 Croatia has ratified international anti-corruption conventions and harmonized national legislation accordingly; corruption is treated as a criminal act.

${ }^{4}$ For a definition of institutions see North, 1990. 
${ }^{5}$ Office for the Suppression of Corruption and Organised Crime.

${ }^{6} \mathrm{http}: / /$ www.antikorupcija.hr.

${ }^{7}$ Even though the survey reveals "petty" administrative corruption and does not capture "grand" political corruption.

\section{REFERENCES}

Baloban, S. and Rimac, I. (1999), Povjerenje u institucije u Hrvatskoj (Confidence in Institutions in Croatia). Bogoslovska smotra, 68 (4): 663-672.

Berggren, N. and Jordahl, H. (2006), Free to Trust: Economic Freedom and Social Capital. Kyklos, 59 (2): 141-169. doi:10.1111/j.14676435.2006.00324.x

Budak, J. (2006), Corruption in Croatia: Perceptions Rise, Problems Remain. Croatian Economic Survey, 9: 35-68.

Budak, J. and Rajh, E. (2010), Surveillance Issues on Reporting Corruption: Case of Corruption Survey in Croatia, Proceedings of the Conference ICT: Development Surveillance, Paneuropean University Apeiron, Banja Luka, Bosnia and Herzegovina, September 17, 2010, pp. 75-86, Banja Luka: Paneuropean University Apeiron.

Haggerty, K. D. and Gazso, A. (2005), The Public Politics of Opinion Research on Surveillance and Privacy. Surveillance \& Society, 3 (2/3): 173-180.

Jain, A. K. (2001), Corruption: A Review. Journal of Economic Surveys, 15 (1): 71-121. doi:10.1111/1467-6419.00133

Jensen, N. M., Li, Q. and Rahman, A. (2007), Heard Melodies are Sweet, but Those Unheard are Sweeter: Understanding Corruption Using Cross-National Firm-Level Surveys, The World Bank Policy Research Working Paper WPS4413, November 2007, Washington, DC: The World Bank.

Kaufmann, D. (1997), Corruption: The Facts. Foreign Policy, 107 (Summer): 114-131. doi:10.2307/1149337

Leff, N. H. (1964), Economic Development through Bureaucratic Corruption. American Behavioral Scientist, 8 (3): 8-14. doi:10.1177/0002764 26400800303

Mauro, P. (1995), Corruption and Growth. The Quarterly Journal of Economics, 110 (3): 681-712. doi: 10.2307/2946696

Nooteboom, B. (2007), Social Capital, Institutions and Trust. Review of Social Economy, 65 (1): 29-53. doi:10.1080/00346760601132154

North, D. C. (1990), Institutions, Institutional Change and Economic Performance, Cambridge, Cambridge University Press.

Radovan, M. (2006), Towards a Surveillance Society. Ekonomska istraživanja, 19 (2): 40-52.

Radovan, M. and Jugo, I. (2006), On Data Gathering and Surveillance. In: B. Aurer and M. Bača (eds.), Proceedings of the 17th International Conference on Information and Intelligent Systems (pp. 435-440), Varaždin, Croatia, September 20-22, 2006, Varaždin, Fakultet organizacije i informatike. 
DRUŠ. ISTRAŽ. ZAGREB GOD. 21 (2012) BR. 2 (116),

STR. $291-313$

BUDAK, J., RAJH, E.: CORRUPTION SURVEY...
Reinikka, R. and Svensson, J. (2006), Using Micro-Surveys to Measure and Explain Corruption. World Development, 34 (2): 359-370. doi:10.1016/j.worlddev.2005.03.009

Sampford, C., Shacklock, A., Connors, C. and Galtung, F. (eds.) (2006), Measuring Corruption, Aldershot, Ashgate.

Schneider, F. and Enste, D. (2002), The Shadow Economy: Theoretical Approaches, Empirical Studies, and Political Implications, Cambridge, Cambridge University Press.

Singer, E., Van Hoewyk, J. and Neugebauer, R. J. (2003), Attitudes and Behavior: The Impact of Privacy and Confidentiality Concerns on Participation in the 2000 Census. Public Opinion Quarterly, 67 (3): 368-384. doi:10.1086/377465

Štulhofer, A. (2004), Perception of Corruption and the Erosion of Social Capital in Croatia 1995-2003. Politička misao, 41 (5): 74-86.

Tanzi, V. (1998), Corruption Around the World: Causes, Consequences, Scope, and Cures. IMF Staff Papers, 45 (4): 559-594, Washington, DC: IMF. doi:10.2307/3867585

Treisman, D. (2007), What Have We Learned About the Causes of Corruption from Ten Years of Cross-National Empirical Research? Annual Review of Political Science, 10: 211-244. doi:10.1146/annurev.polisci. 10.081205.095418

Zipparo, L. (1998), Factors Which Deter Public Officials from Reporting Corruption. Crime, Law and Social Change, 30 (3): 273-287. doi:10.1023/A:1008326527512

\section{Ispitivanje korupcije u Hrvatskoj: povjerliivost ankete i povjerenje $u$ institucije}

Jelena BUDAK, Edo RAJH

Ekonomski institut, Zagreb

Rad polazi od dosadašnje literature o anketama o korupciji, metodološkom problemu odbijanja odgovora o stvarnim iskustvima korupcije te o potencijalnim uzrocima neprijavljivanja korupcije. Studija opisuje konkretnu problematiku $u$ anketnom ispitivanju korupcije i primijenjena rješenja kako bi se smanjio rizik davanja odgovora koji podcjenjuju stvarna korupcijska iskustva građana. $\mathrm{Na}$ temelju Ankete o korištenju javnih usluga i poštenju u javnim službama, provedene u Hrvatskoj 2010. godine, u radu se problem neprijavljivanja korupcije razmatra sa dva stajališta. Najprije se analizira spremnost anketiranih da potvrde svoje sudjelovanje u korupcijskom dielu i razloge odbijanja davanja odgovora. U radu se ispituje percepcija rizika zlouporabe osobnih podataka i mišljenje ispitanika o zaštiti 
DRUŠ. ISTRAŽ. ZAGREB GOD. 21 (2012), BR. 2 (116)

STR. $291-313$

BUDAK, J., RAJH, E. CORRUPTION SURVEY ispitanika i razlozi neprijavljivanja kriminala službenim institucijama. Zasebno se analiziraju formalno i neformalno prijavljivanje korupcije. Rezultati ankete pokazuju visoku razinu oportunizma građana i manjak povjerenja $u$ institucije, što može biti zapreka učinkovitoj provedbi antikorupcijske politike u Hrvatskoj.

Ključne riječi: metodologija anketiranja, korupcijska iskustva, povjerenje $u$ institucije, prijavlijivanje kaznenih djela, Hrvatska 